\title{
SDH Complex Gene Mutation Negative
}

National Cancer Institute

\section{Source}

National Cancer Institute. SDH Complex Gene Mutation Negative. NCI Thesaurus. Code C160571.

A genetic finding indicating that SDH complex mutations have not been detected in a sample. 